\section{Universities and Colleges}

\section{UNIVERSITY OF CAMBRIDGE}

In Congregation on February 23 the following degrees were conferred :

M.B., B.CHIR,-**B. W. C. C. Christopher.

M.B.-B. M. Greenwood, *C. MacG. Williamson, M. S. King, D. J. Allan, J. D. Gorton.

In Congregation on March 9 the following degrees were conferred :

M.B., B.CHrR.- - D. S. Holland

M.B.-A. W. Greer, A. M. Smith, M. R. Colmer, R. A. P. Curtis. *By proxy.

\section{UNIVERSITY OF ABERDEEN}

Dr. John McKenzie has been appointed Reader in Embryology from October 1, 1963.

At Graduation Ceremonies to be held on July 4 and 5, the honorary degree of LL.D. will be conferred on Sir Christopher Andrewes, F.R.S., Deputy Director, National Institute for Medical Research, 1952-61, W. C. Wilson, M.B., Ch.B., F.R.C.S.Ed. Regius Professor of Surgery, University of Aberdeen, 1939-62, and J. S. Young, M.D., Regius Professor of Pathology, University of Aberdeen, 1937-62.

\section{UNIVERSITY OF EDINBURGH}

The honorary status of Junior Research Fellow in the Department of Respiratory Diseases and Tuberculosis has been conferred upon Dr. F. Hafez.

The following were appointed members of the teaching staff Dr. W. N. Eastham, Lecturer in Pathology; Dr. M. D. W. Low, Assistant to Dean (Planning), Faculty of Medicine.

Dr. J. A. D. Anderson has submitted his resignation as Honorary Lecturer in Public Health and Social Medicine from March 31, 1963.

\section{UNIVERSITY OF DUBLIN}

School of Physic, Trinity College

At the recent examination held by the University, the following were awarded the Diploma in Gynaecology and Obstetrics:

S. L. Bisarya. Fakhar-un-Nisa Chaury, J. J. Fryatt, S. A. Irfan, M. O. J.
Jarallah, W. Z. Kammawi, I. K. Khalidi, V. R. S. Lakshmi, Anita Mathias, A. R. K. Shunnar, A. E. M. I. Sultan.

\section{UNIVERSITY OF LONDON}

Dr. J. B. Cavanagh, Research Fellow in Neuropathology at Guy's Hospital Medical School, has been appointed to the Readership in Neuropathology tenable at that School.

\section{UNIVERSITY OF BIRMINGHAM}

Dr. J. M. Malins has been reappointed a representative of the University on the governing body of King Charles I School, Kidderminster.

The title of Senior Clinical Tutor has been conferred on Mr. P. G Bevan, Consulting Surgeon at the Dudley Road Hospital, from December 1, 1962.

The title of Honorary Research Fellow has been conferred on the following during the tenure of their present awards or for the period of their stay in the University: Dr. D. M. Mitchell, who is working in the Department of Experimental Pathology; Dr. C. Osorio, of the M.R.C. Staff, who has been seconded to work in the Department of Experimental Pathology Dr. G. I. Horsfield, who is a member of the staff of the M.R.C. Unit for Research on the Experimental Pathology of the Skin.

\section{UNIVERSITY OF LIVERPOOL}

The following candidates have been approved at the examinations indicated.

PH.D.-In the Faculty of Medicine : M. B. Skirrow, M.B., Ch.B. Diploma In RAMOLOGY: Radiodiagnosis, Part I.-A. Ahandrik, Jean D Ames, Beatrice Beulab, M. J. Brindle, F. G. Condon, J. C. Craig, M. 1. Radiotherap, Part I: Mary W. Rish, M. A J Shakir, L. Wanamkang.

\section{ROYAL COLLEGE OF SURGEONS OF ENGLAND}

At a meeting of the Council of the College held on March 14, with Sir Arthur Porritt, Bt., President, in the chair, Mr. Robert V. Cooke was presented with the Cecil Joll Prize for 1963 for meritorious work in the field of general surgery and in thyroid surgery in particular.
Sir Miles Clifford, K.B.E. (Director, Leverhulme Trust), Dr. Jean Deliberos (President, International Dental Federation), and Sir Harry Platt, Bt. (Past President of the Royal College of Surgeons of England), were elected to the Honorary Fellowship in Dental Surgery.

Dr. P. M. F. Bishop, Endocrinologist at Guy's Hospital and Chelsea Hospital for Women, was appointed Sir Arthur Sims Commonwealth Travelling Professor for 1964, to visit Australia and New Zealand, Malaya, Singapore, and Fiji.

Mr. Neville E. Stidolph, of the Whittington Hospital, was appointed Penrose May Surgical Tutor in the College.

The Hallett Prize was awarded to P. B. Deverall, of University College Hospital Medical School.

A Moynihan Lectureship was awarded to Dr. Charles Huggins, Hon.F.R.C.S., of the University of Chicago.

The results were reported of the Primary F.R.C.S. examinations held in Colombo and Calcutta. Eleven candidates were successful out of 37 entrants in Colombo, and 21 out of 114 in Calcutta.

Diplomas of Fellowship were granted to S. G. Koorey and C. P. De Silva.

After the meeting a Hunterian Lecture was delivered by Professor J. Angell James on "New Developments in the Ultrasonic Therapy of Ménière's Disease."

\section{Faculty of ANaEsthetists}

The Election to the Board of the Faculty of Anaesthetists took place in the College on March 13. As the result of a postal ballot Dr. R. W. Cope (University College Hospital), Dr. A. H. Galley (King's College Hospital), and Dr. A. J. W. Beard (Hammersmith Hospital) were re-elected to the Board.

\section{ROYAL COLLEGE OF OBSTETRICIANS AND} GYNAECOLOGISTS

At a meeting of the Council of the College held on January 26 , with the President, Mr. Arthur C. H. Bell, in the chair, the following were elected to the Membership:

D. A. Aitken, P. G. Asolkar, S. K. Basu, J. F. S. Batson, R. W. Beard, T. Belo-Osagie. R. G. Blumer, E. G. Bosch, T. P. Boulle, D. M Buchanan, R. M. Burton, E. B. Caldwell, B. N. Chakravarty, C. B Chaurasia, G. C. M. Clarke, S. V. Clerk, D. V. Cohen, A. P. Condie. Davies, G. I. Dhall, S. Dhall, S. Dharmalingam, M. M. Dutta, R. K Dutta, B. A. Fernando, W. S. C. Fernando, G. J. Gartlan, P. W. Gasson, S. W. George, A. K. Ghosh, G. T. Goodey. E. S. Grech, P. K. Guha, D. Mck. Hart, C. N. Hudson, J. G. Hill, E. A. Ikomi, Hannah E. Jacoby, Christine M. L. Kerr, O. Lartey, M. M. M. Lebbe, Mary M. Lloyd Lalitha Loganadan, B. N. McAdam, C. J. Macaulay, R. S. McCoy, M. G. H. Mayat A. Mehta, B. A. Mills, N. O. Mohammed, B. Mukherjec Helen C. Murrell, Dolly F. Namdarian, J. S. Newlinds, B. K. O'Farrell. G. A. O'Neill, M. N. Oo, H. M. Patel, P. S. Perera, K. R. S. Pool, D. K. Quinlan, H. S. Radden, C. Rao, N. K. Rengarajan, M. B. Rivlin Yvonne E. Rotchell, J. H. Scudamore, S. K. Seal, K. T. Shah, W. Y. Sinclair, A. Sinha, T. A. Sinnathuray, Margaret Smith, Rita Smith, Mary L. Stokes, R. W. Taylor, K. Thevarajah, A. D. Thursz, K. J. Tompkins, S. T. Trezise, J. J. H. B. Van Der Wat, R. A. Watkins, A. J. White, Jennifer C. Wilson, M. J. Yates.

Mr. W. J. Garratt (Sydney, Australia) and Dr. P. J. Huntingford (London) have been appointed William Blair-Bell Memorial Lecturers for 1963

Dr. R. T. Booth has been awarded the Green-Armytage Shortterm Travelling Scholarship for 1963 to visit Denmark, Sweden, and Finland.

\section{NOTES AND COMMENTS}

Correction.-We much regret that Dr. G. I. Watson's designation was given as "Assistant Medical Officer, S.W. Division, Surrey County Council " at the foot of his preliminary communication on "Protection After Exposure to Measles by Attenuated Vaccine Without Gamma-globulin" (March 30, p. 860). This study was done in general practice, not as School Medical Officer.

All communications with regard to editorial business should be addressed to THE EDITOR, British MEDICAL JOURNAL, B.M.A. HOUSE, TAVISTOCE SQUARE, LONDON, W.C.1. TELEPHONE: EUSTON 4499. TELEORAMS: Aithology, Westcent, London. ORIGINAL ARTICLES AND LETTBRS Medical Journal alone unless the contrary be stated. Medical Journal alone unless the contrary be stated. Mesiring REPRINTS should communicate with the Publishing Manazer. B.M.A. House, Tavistock Square, W.C. On recelpt of proofs For details see inside the back cover Marc 30 issue. For details see inside the back cover March 30 issue. MEMBBRS' SUBSCRIPTIONS should be sent to the SECRETARY of the British Medical Association. TELEPHONE: EUSTON 4499.

B.M.A. ScotTISH OFFICE: 7, Drumsheugh Gardens, Edinburgh. 